University of Nebraska - Lincoln

DigitalCommons@University of Nebraska - Lincoln

Faculty Papers and Publications in Animal

Science

Animal Science Department

August 2000

\title{
Effects of genetic type and protein levels on growth of swine
}

O.W. Robison

North Carolina State University

L. L. Christian

lowa State University

R. Goodwin

National Pork Producers Council

R. K. Johnson

National Pork Producers Council, rjohnson5@unl.edu

J. W. Mabry

University of Georgia

See next page for additional authors

Follow this and additional works at: https://digitalcommons.unl.edu/animalscifacpub

Part of the Animal Sciences Commons

Robison, O.W.; Christian, L. L.; Goodwin, R. ; Johnson, R. K.; Mabry, J. W.; Miller, R. K.; and Tokach, M. D., "Effects of genetic type and protein levels on growth of swine" (2000). Faculty Papers and Publications in Animal Science. 57.

https://digitalcommons.unl.edu/animalscifacpub/57

This Article is brought to you for free and open access by the Animal Science Department at DigitalCommons@University of Nebraska - Lincoln. It has been accepted for inclusion in Faculty Papers and Publications in Animal Science by an authorized administrator of DigitalCommons@University of Nebraska - Lincoln. 


\section{Authors}

O.W. Robison, L. L. Christian, R. Goodwin, R. K. Johnson, J. W. Mabry, R. K. Miller, and M. D. Tokach 


\title{
Effects of genetic type and protein levels on growth of swine
}

\author{
O. W. Robison ${ }^{*}$, , L. L. Christian ${ }^{\dagger}$, R. Goodwin ${ }^{\ddagger}$, R. K. Johnson ${ }^{\S}$, \\ J. W. Mabry ${ }^{\#}$, R. K. Miller ${ }^{\dagger \dagger}$, and M. D. Tokach \\ "North Carolina State University; ${ }^{\dagger}$ Iowa State University; ${ }^{\dagger}$ National Pork Producers Council; \\ ${ }^{\S}$ University of Nebraska; ${ }^{\#}$ University of Georgia; ${ }^{\dagger \dagger}$ Texas A\&M University; and ${ }^{* \dagger}$ Kansas State University
}

\begin{abstract}
A total of 1,588 pigs representing six genetic lines were included in this study. These lines were selected to represent a wide range of biological types for appetite, rate and composition of gain, and meat quality traits. Each line was fed four different diets differing in lysine content. Barrows and gilts were used in the experiment, and pigs were randomly assigned to come off test at one of three weights $(113.6,131.8$, or $150 \mathrm{~kg})$. Rates of increase in weight, backfat thickness, and longissimus muscle area were essentially linear. Genetic type and diet influenced $(P<.05)$ rates of change in weight, backfat thickness, and longissimus muscle area and 10th rib fat depth, carcass longissimus muscle area, and dressing percentage. Genetic type $\times$ diet interactions were significant for weight change and 10th rib fat. As off-test-weight class increased fat and longissimus muscle area increased in linear fashion. In general, interactions associated with diet resulted from feeding the diet lowest in lysine. There was little evidence of genetic type $\times$ diet interactions. If those interactions that tested significant are real, they are a result of extremes in both genetic type (high fatness) and lysine level (low). Slaughtering pigs at heavier weights results in no change in rate of gain over the feeding period and linear increases in longissimus muscle area and backfat thickness.
\end{abstract}

Key Words: Pigs, Genetics, Lysine, Growth

\section{Introduction}

In designing modeling programs, it is necessary to understand how pigs grow. The effects of genetic type, diet, sex, and market weight, as well as interactions among these effects, could influence modeling programs greatly.

The Genetics Program Committee of the National Pork Producers Council initiated a study to provide information for lean growth modeling. Six genetic types were selected to represent a wide range of biological types, differing in rate of gain, fatness, appetite, and muscle quality. Likewise, four diets with a wide range in lysine levels were chosen. Because sex and market weights may be important considerations in modeling, barrows and gilts were included in the test and three market weights were included in the design.

The major objectives of the study were to document how pigs grow and to evaluate the two-way interactions among genetic types, diet, sex, and market weight class.

\section{Materials and Methods}

A total of 1,588 pigs were used in the study. Six genetic types represented a wide range of biological types differing in rate of gain, fatness, appetite, and muscle quality. Genetic lines were not sampled in a manner to make valid comparisons among lines. Thus, lines are identified by letter only. As with genetic type, diets were designed to give a wide range in lysine levels; our goal was not to determine the best diet (Table 1). Thus, six genetic types, four diets, two sexes, and three off-test-weights $(113.6,131.8$, and $150 \mathrm{~kg}$ ) were used in a factorial design. Pigs entered segregated early-weaning nurseries at 8 to $9 \mathrm{~d}$ of age and started on test at approxi- mately $45 \mathrm{~kg}$. Pigs were then weighed and scanned by ultrasound for backfat thickness and longissimus muscle area (LMA) at 2- to 3-wk intervals until the end of test. Pigs were assigned at random to end the test at $113.6,131.8$, or $150 \mathrm{~kg}$. Carcass 10th rib fat and LMA were obtained for all pigs.

Linear rates of change in weight, backfat, and LMA were calculated for each pig. These regression coefficients were analyzed for effects of genetic type, diet, sex, off-test-weight group, and all two-way interactions. Carcass 10th rib fat and LMA were analyzed using the same model.

\section{Results and Discussion}

The major objectives of the study were to document how pigs grow and to evaluate genotype $x$ diet interactions. Linear and linear plus quadratic regressions of weight on dayson- test, backfat on weight, and LMA on weight were calculated for each pig. The $\mathrm{R}^{2}$ values for linear regressions were approximately .98, .94, and .94 for weight, backfat, and LMA, respectively, with small variations among lines. The quadratic term added approximately .005 for weight and approximately .025 for backfat and LMA. Thus, linear regression coefficients were used in the statistical analyses. Genetic type, diet, sex, replicate, off-test-weight class, and all two-way interactions were included in the model.

Rates of change by line are shown in Table 2 and by diet in Table 3. The experimental design resulted in a wide range among lines and diets for all traits. Line A clearly deposited fat at the highest rate and had the lowest increase in LMA, but it was intermediate for body weight change. Line D had the highest rate of change in body weight, and it was intermediate for the other traits. Differences among the lines in 
the way they grow are evident. Likewise, diets significantly influenced all traits; higher body weight changes and lower fat deposition were observed among pigs fed higher-lysine diets.

\section{Weight Changes}

Rate of gain was significantly influenced by genetic type, diet, sex, genetic type $\times$ diet interaction, and diet $\times$ sex interaction. Off-test-weight classes (Table 4) did not influence gain $(P>.05)$, nor were there any interactions with other variables. Body weight gains for diet $\times$ genetic type subclass are given in Table 5. Lines C, D, and E had little or no change in rate of gain on the four diets. Line $\mathrm{B}$ had a large decease in gain on diet 4 , and Line A had a decrease on diet 1. In neither line was there a trend across diets, but there was a large decrease among pigs on the extreme diet. These may well be artifacts, because other lines with similar backfat and(or) gain were not similarly affected. For example, Line C performed very similarly to Line B but did not show a decrease in gain on diet 4 . Although Line A was much fatter than any other line, the two lines closest in fat deposition (Lines D and F) did not show adverse effects of high lysine. Thus, if a genetic type $\times$ diet interaction does exist, it is present only for very extreme diets and genetic types.

The diet $\times$ sex interaction resulted from barrows performing the same across diets, whereas gilts tended to have reduced gains as lysine level decreased (Table 6).

\section{Backfat Disposition}

Rate of fat deposition was affected $(P<.05)$ by genetic type, diet, sex, off-test-class, and genetic type $\times$ sex interaction. Although both genetic type and diet had significant effects on fat deposition, there was no indication of an interaction between them. In general, fat deposition increased as lysine level decreased (Table 7).

The genetic type $\times$ sex interaction was a result of large differences between sexes for some lines and small differences for other lines. Lines with higher rates of fat deposition had larger differences between sexes than lines with lower rates of fat deposition (Table 8).

\section{Longissimus Muscle Area}

Only genetic type and diet significantly influenced LMA. Off-test-weight group and genetic type $\times$ diet had probability values of approximately .12. These results are confusing because the highest rates of LMA increase are for the two intermediate levels of lysine for all genetic types (Table 9). Line B, which had the highest rate of increase in LMA, showed no change in LMA deposition across lysine levels, but the two lines (A and D) with the most backfat tended to lower increases in LMA with the lowest level of lysine. Offtest-weight classes showed some small increases in LMA deposition as off-test-weight increased. As expected, gilts had slightly higher $(P>.05)$ rates of LMA deposition than barrows.

\section{Carcass Loin Muscle Area}

Genetic type, diet, sex, off-test-weight, genetic type $\times$ off-test-weight, and diet $\times$ sex influenced $(P<.05)$ carcass LMA. Tables 10 and 11 present means by genetic type and diet, respectively. There were large differences among genetic types. Diets 1 and 2 were not different for LMA, diet 3 showed a modest reduction in LMA, and diet 4 had a large reduction in LMA.

Off-test-weight class effects supported the concept of a linear increase in LMA as weight increased (Table 12). There tended to be larger increases in LMA with heavier weights for lines with large LMA than for lines with smaller LMA (Table 13). Gilts had a larger decrease than barrows in LMA as lysine level decreased (Table 14). It should be noted that the targeted off-test-weight of $150 \mathrm{~kg}$ was not reached; the actual off-test-weight for this class was $145 \mathrm{~kg}$.

\section{0th Rib Fat}

Genetic type, diet, sex, off-test-weight, genetic type $\times$ diet, and genetic type $\times$ sex had significant effects on 10th rib fat. The diet effect (Table 15) seemed to be due entirely to the lowest level of lysine (diet 4). Results of the off-testweight classes reinforced the concept of a linear increase in fat as weight increased (Table 12). As with live animal measures, fatter genetic types had larger differences between sexes than leaner genetic types (Table 16). All genetic types tended to have more 10th rib fat as lysine level decreased. However, the increase tended to be larger for the fatter lines than for the less-fat lines.

\section{Dressing Percentage}

Genetics, diet, and off-test-weight had significant influences on dressing percentage. Dressing percentage increased as lysine decreased and as off-test-weight increased. Fairly large differences existed among genetic types. However, no interactions were evident.

\section{Ham ,Loin, Shoulder, and Belly Percentage}

Genetic type influenced all cuts, and diet and sex effected changes $(P<.05)$ in ham and belly percentages. Market weight had effects on ham and loin and belly percentages $(P<.05)$. Although significant, the effects of diet, sex, and off-test-weight were small.

\section{Conclusions}

The experiment was successful in creating large differences among genetic types and diets. However, there was little evidence for genetic type $\times$ diet interaction. When these interactions were significant, it was primarily due to extremes in both genetic type and diet. The genetic type $\times$ diet interaction for weight change may well be an artifact. The other interactions were due to a scaling effect, with fatter lines 
having larger increases in fat deposition than leaner lines as lysine in the diet decreased.

Results from this study reinforce those from previous studies that have shown linear increases in body weight with age and linear increases in fat and LMA as weight increases. This was true for all genetic types and diets. Slaughtering pigs at heavier weights results in no change in ADG over the feeding period and linear increases in LMA and backfat.

\section{Implications}

Weight, lean, and fat increase in a linear fashion in pigs. In general, weight change seems to increase and backfat deposition seems to decrease as dietary lysine is increased. However, there is little suggestion of different genetic types needing different lysine levels. Cost of lysine will probably determine which diet should be used. Linear models would seem to be adequate for all genetic types. Linear models for genetic type, lysine level, sex, and off-test-weight will make modeling easier.

\section{Notes}

1. Correspondence: Department of Animal Science, Box 7621, North Carolina State University, Raleigh, NC 27695 (phone: 919-515-4015; fax: 919-5150-7780; Email: OW_Robison@ncsu.edu. 
Table 1. Nutrition programs

\begin{tabular}{|c|c|c|c|c|c|c|}
\hline \multirow{2}{*}{$\begin{array}{l}\text { Metabolized } \\
\text { energy, kcal }\end{array}$} & \multirow{2}{*}{$\begin{array}{c}\text { Pig wt, } \\
\text { kg }\end{array}$} & \multirow{2}{*}{$\begin{array}{l}\text { Added } \\
\text { fat, } \%\end{array}$} & \multicolumn{4}{|c|}{ Lysine levels per diet, $\%$} \\
\hline & & & 1 & 2 & 3 & 4 \\
\hline 1,598 & $41-64$ & 5 & 1.25 & 1.10 & .95 & .80 \\
\hline 1,560 & $65-86$ & 3 & 1.10 & .95 & .80 & .65 \\
\hline 1,501 & $87-109$ & 0 & .95 & .80 & .65 & .50 \\
\hline 1,502 & $110-132$ & 0 & .80 & .65 & .50 & .35 \\
\hline 1,502 & $133-150$ & 0 & .80 & .65 & .50 & .35 \\
\hline
\end{tabular}

Table 2. Rates of change for body weight, backfat (BF), and longissimus muscle area (LMA) by genetic type

\begin{tabular}{lccc}
\hline Genetic type & ADG, $\mathrm{kg}$ & $\mathrm{BF}, \mathrm{mm}^{\mathrm{a}}$ & ${\text { LMA }, \mathrm{cm}^{2 \mathrm{a}}}^{\mathrm{A}}$ \\
\hline $\mathrm{A}$ & .744 & .248 & .206 \\
$\mathrm{~B}$ & .726 & .158 & .282 \\
$\mathrm{C}$ & .753 & .153 & .250 \\
$\mathrm{D}$ & .798 & .187 & .236 \\
$\mathrm{E}$ & .721 & .152 & .247 \\
$\mathrm{~F}$ & .712 & .182 & .254 \\
$\mathrm{SE}$ & \pm .009 & \pm .006 & \pm .007 \\
\hline
\end{tabular}

${ }^{\mathrm{a}}$ Rates of change in backfat and LMA per kilogram of body weight.

Table 3. Rates of change in body weight, backfat (BF), and longissimus muscle area (LMA) by protein level

\begin{tabular}{lccc}
\hline Diet & ADG, $\mathrm{kg}$ & $\mathrm{BF}, \mathrm{mm}^{\mathrm{a}}$ & LMA, $\mathrm{cm}^{2 \mathrm{a}}$ \\
\hline 1 & .753 & .166 & .237 \\
2 & .748 & .171 & .258 \\
3 & .744 & .183 & .258 \\
4 & .721 & .200 & .229 \\
$\mathrm{SE}$ & \pm .007 & \pm .005 & \pm .005 \\
\hline
\end{tabular}

${ }^{a}$ Rates of change in BF and LMA per kilogram of change in body weight. 
Table 4. Rates of change in body weight, backfat (BF), and longissimus muscle area (LMA) by market weight groups

\begin{tabular}{lccc}
\hline Market weight, $\mathrm{kg}$ & $\mathrm{ADG}, \mathrm{kg}$ & $\mathrm{BF}, \mathrm{mm}^{\mathrm{a}}$ & $\mathrm{LMA}, \mathrm{cm}^{\mathrm{a}}$ \\
\hline 113.64 & .767 & .154 & .240 \\
131.82 & .767 & .192 & .243 \\
150 & .762 & .193 & .254 \\
$\mathrm{SE}$ & & \pm .004 & \pm .005 \\
\hline
\end{tabular}

${ }^{\text {a }}$ Rates of change in BF and LMA per kilogram of change in body weight.

Table 5. Rates of increase in body weight $(\mathrm{kg})$ by genetic type and diet ${ }^{\mathrm{a}}$

\begin{tabular}{lcccc}
\hline & \multicolumn{4}{c}{ Diet } \\
\cline { 2 - 5 } $\begin{array}{l}\text { Genetic } \\
\text { type }\end{array}$ & 1 & 2 & 3 & 4 \\
\hline $\mathrm{A}$ & .722 & .762 & .744 & .748 \\
$\mathrm{~B}$ & .767 & .730 & .753 & .653 \\
$\mathrm{C}$ & .753 & .767 & .744 & .739 \\
$\mathrm{D}$ & .812 & .798 & .803 & .785 \\
$\mathrm{E}$ & .748 & .712 & .712 & .717 \\
$\mathrm{~F}$ & .726 & .726 & .717 & .680 \\
\hline a SE $=017$ & & &
\end{tabular}

Table 6. Rates of increase in body weight $(\mathrm{kg})$ by sex and $\operatorname{diet}^{\mathrm{a}}$

\begin{tabular}{lcc}
\hline & \multicolumn{2}{c}{ Sex } \\
\cline { 2 - 3 } Diet & Barrows & Gilts \\
\hline 1 & .767 & .739 \\
2 & .767 & .730 \\
3 & .776 & .712 \\
4 & .758 & .680 \\
\hline
\end{tabular}

${ }^{\mathrm{a}} \mathrm{SE} \pm .009$. 
Table 7. Rates of increase in backfat (mm) per kilogram of body weight gain ${ }^{\mathrm{a}}$

\begin{tabular}{lcccc}
\hline & \multicolumn{3}{c}{ Diet } \\
\cline { 2 - 5 } Genetic type & 1 & 2 & 3 & 4 \\
\hline $\mathrm{A}$ & .230 & .255 & .227 & .275 \\
$\mathrm{~B}$ & .128 & .162 & .168 & .168 \\
$\mathrm{C}$ & .150 & .130 & .172 & .160 \\
$\mathrm{D}$ & .165 & .170 & .196 & .214 \\
$\mathrm{E}$ & .134 & .132 & .153 & .190 \\
$\mathrm{~F}$ & .187 & .175 & .173 & .191 \\
\hline
\end{tabular}

${ }^{\mathrm{a}}$ Rates of change in backfat deposition per kilogram of change in body weight ( $\left.\mathrm{SE} \pm .012\right)$.

Table 8. Rates of change in backfat $(\mathrm{mm})^{\mathrm{a}}$ by genetic type and sex

\begin{tabular}{lcc}
\hline & \multicolumn{2}{c}{ Sex } \\
\cline { 2 - 3 } Genetic type & Barrows & Gilts \\
\hline $\mathrm{A}$ & .282 & .213 \\
$\mathrm{~B}$ & .174 & .141 \\
$\mathrm{C}$ & .184 & .123 \\
$\mathrm{D}$ & .207 & .167 \\
$\mathrm{E}$ & .173 & .131 \\
$\mathrm{~F}$ & .222 & .141 \\
\hline
\end{tabular}

${ }^{\mathrm{a} C}$ Change per kilogram of body weight $(\mathrm{SE} \pm .009)$. 
Table 9. Rates of change in longissimus muscle area (LMA, $\mathrm{cm}^{2}$ ) per kilogram of increase in body weight ${ }^{\mathrm{a}}$

\begin{tabular}{lcccc}
\hline & \multicolumn{5}{c}{ Diet } \\
\cline { 2 - 5 } Genetic type & 1 & 2 & 3 & 4 \\
\hline $\mathrm{A}$ & .207 & .219 & .217 & .183 \\
$\mathrm{~B}$ & .285 & .288 & .282 & .273 \\
$\mathrm{C}$ & .231 & .251 & .284 & .234 \\
$\mathrm{D}$ & .247 & .234 & .257 & .204 \\
$\mathrm{E}$ & .210 & .278 & .253 & .246 \\
$\mathrm{~F}$ & .240 & .282 & .263 & .234 \\
\hline
\end{tabular}

${ }^{\mathrm{a}}$ Rates of change in LMA per kilogram of change in body weight $(\mathrm{SE} \pm .014)$.

Table 10. Effects of genetic type on longissimus muscle area (LMA) and 10th rib fat

\begin{tabular}{lcc}
\hline & \multicolumn{2}{c}{ Trait } \\
\cline { 2 - 3 } Genetic type & LMA, cm ${ }^{2}$ & 10th rib fat, mm \\
\hline A & 36.07 & 38.86 \\
B & 45.62 & 25.15 \\
C & 43.29 & 25.91 \\
D & 41.36 & 30.23 \\
E & 42.65 & 25.65 \\
F & 45.29 & 28.70 \\
SE & \pm .335 & \pm .432 \\
\hline
\end{tabular}


Table 11. Effects of lysine level on longissimus muscle area (LMA) and 10th rib fat

\begin{tabular}{ccc}
\hline & \multicolumn{2}{c}{ Trait } \\
\cline { 2 - 3 } Diet & LMA, cm ${ }^{2}$ & 10th rib fat, mm \\
\hline 1 & 43.62 & 27.94 \\
2 & 43.81 & 27.94 \\
3 & 42.65 & 28.96 \\
4 & 39.49 & 31.50 \\
SE & \pm .284 & \pm .356 \\
\hline
\end{tabular}

Table 12. Effects of market weight on longissimus muscle area (LMA) and 10th rib fat

\begin{tabular}{lcc}
\hline & \multicolumn{2}{c}{ Trait } \\
\cline { 2 - 3 } Market weight, $\mathrm{kg}$ & LMA, cm ${ }^{2}$ & 10th rib fat, mm \\
\hline 116.36 & 39.55 & 25.15 \\
132.73 & 42.39 & 29.72 \\
145 & 45.23 & 32.51 \\
$\mathrm{SE}$ & \pm .245 & \pm .305 \\
\hline
\end{tabular}

Table 13. Effects of genetic group $\times$ market weight on longissimus muscle area (LMA, $\left.\mathrm{cm}^{2}\right)^{\mathrm{a}}$

\begin{tabular}{lrrr}
\hline & \multicolumn{3}{c}{ Market weight, kg } \\
\cline { 2 - 4 } Genetic group & 116.36 & 132.73 & 145 \\
\hline A & 34.07 & 36.52 & 37.62 \\
B & 41.94 & 45.87 & 49.10 \\
C & 40.13 & 42.97 & 46.84 \\
D & 39.42 & 40.65 & 44.07 \\
E & 39.94 & 42.52 & 45.49 \\
F & 41.74 & 46.00 & 48.20 \\
\hline
\end{tabular}

${ }^{\mathrm{a}} \mathrm{SE} \pm .613$. 
Table 14. Effects of diet $\times$ sex on longissimus muscle area $(\mathrm{LMA}, \mathrm{cm})^{2 \mathrm{a}}$

\begin{tabular}{|c|c|c|}
\hline \multirow[b]{2}{*}{ Diet } & \multicolumn{2}{|c|}{ Sex } \\
\hline & Male & Female \\
\hline 1 & 41.94 & 45.23 \\
\hline 2 & 41.87 & 45.74 \\
\hline 3 & 41.29 & 44.00 \\
\hline 4 & 38.65 & 40.26 \\
\hline
\end{tabular}

${ }^{\mathrm{a}} \mathrm{SE} \pm .413$

Table 15. Genetic group $\times$ diet effects on 10 th rib fat $(\mathrm{mm})^{\mathrm{a}}$

\begin{tabular}{lcccc}
\hline & \multicolumn{3}{c}{ Diet } \\
\cline { 2 - 5 } Genetic group & 1 & 2 & 3 & 4 \\
\hline A & 35.31 & 38.35 & 38.61 & 42.93 \\
B & 23.62 & 24.64 & 25.15 & 27.18 \\
C & 24.38 & 25.40 & 26.92 & 27.18 \\
D & 28.70 & 29.72 & 29.46 & 33.27 \\
E & 26.92 & 22.61 & 25.15 & 27.69 \\
F & 27.94 & 26.42 & 28.70 & 31.24 \\
\hline
\end{tabular}

${ }^{\mathrm{a}} \mathrm{SE} \pm .889$.

Table 16. Genetic group by sex effects on 10th rib fat $(\mathrm{mm})^{\mathrm{a}}$

\begin{tabular}{lcc}
\hline & \multicolumn{2}{c}{ Sex } \\
\cline { 2 - 3 } Genetic group & Barrows & Gilts \\
\hline A & 42.16 & 35.31 \\
B & 26.92 & 23.11 \\
C & 28.45 & 23.39 \\
D & 33.02 & 27.69 \\
E & 27.69 & 23.62 \\
F & 31.75 & 25.40 \\
\hline
\end{tabular}

${ }^{\mathrm{a}} \mathrm{SE} \pm .635$. 